九州大学学術情報リポジトリ

Kyushu University Institutional Repository

\title{
Studies on the denaturation of proteins with sodiump-aminosalicylate (PAS)
}

Funatsu, Masaru

Biochemical Laboratory, Department of Agriculture, Kyushu University

https://doi.org/10.5109/22680

出版情報: 九州大学大学院農学研究院紀要. 11 (2)，pp. 129-154，1959-08. Kyushu University バージョン：

権利関係 : 
Journal of the Faculty of Agriculture, Kyūshū University, Vol. 11, No. 2

August 31, 1959

Studies on the denaturation of proteins with sodiump-aminosalicylate (PAS)

Masaru Funatsu

INTRODUCTION

It has been reported by Yoshinari ${ }^{109}$ that the prevention of blood coagulation with PAS was due to the inhibition of fibrin formation. This is because PAS dissolves profibrin. Besides profibrin, however, almost all kinds of proteins are very easily dissolved with PAS. The relationship of the chemical structure of PAS to that of amide compounds suggested that the polarity of the PAS molecule accounts for the dissolving of proteins.

PAS is considered to have two actions in dissolving proteins. First, this compound, like glycine, ${ }^{40)}$ increases the dielectric constant of the solvent. If this is actually true, proteins in the PAS solution would not undergo denaturation. Second, PAS, like urea, acetamide, and guanidine, breaks down hydrogen bonds between peptide chains and is bound to the liberated peptide linkages. ${ }^{93)}$ If the latter is the main reason for the dissolving of proteins, proteins can be expected to be denatured by the dissociation or unfolding of their peptide chains. It is also probable that the disaggregation of proteins ${ }^{12-15,34,35,48,63,76,43 j}$, $43,96,105,103)$ would take place in the concentrated PAS solution the same as did in the concentrated urea solution.

To explain the mode of the dissolving action of PAS and elucidate the mechanism of denaturation, if denaturation occurred, the author estimated the sedimentation constants, the diffusion constants, and the intrinsic viscosities of serum albumin, ovalbumin, and hemoglobin in concentrated PAS solution, comparing these with those of native proteins. The molecular weights, and the frictional and axial ratios 
of the above mentioned proteins were determined from these measurements.

From these data it has been concluded that proteins appeared to undergo denaturation in concentrated PAS solution. The binding of PAS by protein was also assumed to play the most important role in the PAS-denaturation. This was ascertained by measuring the amounts of PAS bound by proteins, and by the properties of the monolayer film formed with protein denatured by PAS.

The conception of the PAS-denaturation mechanism was discussed by studying the optical rotations of denatured proteins, and by considering the ionization of PAS and protein.

\section{EXPERIMENTAL}

\section{Experimental Materials}

\section{Proteins :}

Serum albumin (horse): Crystallized from fresh horse blood by the method of McMeekin. $\left.{ }^{4,} 69,107\right)$

Ovalbumin (chicken): Crystallized from fresh eggs by the method of Sörensen and Höyrup. ${ }^{55,61,92)}$

Hemoglobin (horse) : Crystallized from horse red corpuscles by the usual method.

These proteins were lyophilized by the freeze-dry method after electrodialysis. Examination by ultracentrifugation and electrophoresis revealed that they were homogeneous.

Sodium-p-Aminosalicylate (PAS) :

Commercial PAS was twice recrystallized. m.p. $112^{\circ} \mathrm{C}$. (decomp.)

\section{Experimental Methods}

1. The estimation of the sedimentation constants ${ }^{67}, 71$ )

Using Spinco's Model E Ultracentrifuge, the sedimentation constants of the proteins were estimated from the rate of sedimentation in phosphate solution containing PAS (in this article the proteins dissolved in this solution were represented as "PAS treated or denatured proteins"), and in a solution of $0.05 \mathrm{M}$ phosphate and $0.2 \mathrm{M} \mathrm{NaCl}$ (as "native proteins").

The values of st of serum albumin and hemoglobin were calculated by the usual equation;

$$
\mathrm{st}=\frac{x_{n}-x_{n-1}}{\left(\begin{array}{c}
x_{n}+x_{n-1} \\
2
\end{array}\right) w^{2} \Delta t}
$$


where $x$ is the distance from the axis of rotation and $x_{n}$ and $x_{n-1}$ refer to positions of boundaries at time $t_{n}$ and $t_{n-1}, w$ is the rotational speed in radians per second and $\Delta t$ is the difference between $t_{n}$ and $t_{n-1}$ in seconds.

Since the boundary of ovalbumin in the PAS solution was not obtainable by the above method, the value of st of ovalbumin was calculated by the methods of Baldwin," and of Gutfreund and Ogston. ${ }^{3 i}$ The value of st by Baldwin's method was obtained by the following equation.

$$
\text { st }-\frac{2.303}{2 w^{2} \cdot t}\left\{-\log \left(1-\frac{x \sum_{i}\left(x_{i}-x_{0}\right)^{2}\left(\frac{d n}{d x}\right)_{i}+2 x_{0} \Delta x \sum_{i}\left(x_{i}-x_{0}\right)\left(\frac{d n}{d x}\right)_{i}}{N_{01} x_{0}{ }^{2}}\right)\right\}
$$

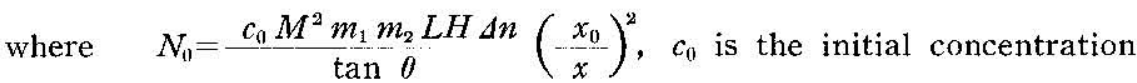

of protein, $M$ is the degree of magnification of the enlarged photograph of the boundary, $m_{1}$ is the degree of magnification of the camera lens; $2.17, m_{2}$ is that of cylindrical lens; $3.49, L$ is the length of the optical arm; $58.1 \mathrm{~cm}, H$ is the thickness of the cell $(\mathrm{cm}), \theta$ is the magnitude of the bar angle, and $\Delta n$ is the refraction increment; $0.00186 . x, t$, $w$ are given as the same as mentioned above.

The value of st was also obtained by the following equation, given by Gutfreund and Ogston,

$$
\mathrm{st}=\frac{2.303}{2 w^{2}} \cdot b
$$

where $b$ is given from the equation;

$$
b=-\log \left\{1-\frac{2 Q^{\prime} t}{c_{0} x_{0}{ }^{3}}\right\} \frac{1}{t}
$$

and

$$
Q^{\prime}=\int_{x}^{x} x \int_{x}^{x} x \frac{d c}{d x} d x d x
$$

moreover

$$
\int_{\infty}^{x} \frac{d c}{d x} d x=-\frac{1}{K} \int_{x}^{x} \frac{d n}{d x} d x
$$

Here, $K$ is 12.68 .

The correction of st for the concentration of protein was carried out as follows. The corrected value $s_{\mathfrak{y}}$ is given by st $(1+k c)$, where $k$ is obtained from the values of intrinsic viscosities in any case where $k$ is more or less than 8 . 


$$
\begin{aligned}
k & =0.75[\eta]+5 & \text { where } \quad k<8 \\
k & =[\eta]+5.5 & \text { where } \quad k>8
\end{aligned}
$$

After the corrections were made for temperature and the influence of the solvent, the sedimentation constant, $s_{211 u}$, was obtained by the following equation;

$$
s_{2010}=s_{0} \cdot \frac{\eta_{t}}{\eta_{t w}} \cdot \frac{\eta_{t w w}}{\eta_{211 t c}} \cdot \frac{\left(1-V_{20} \rho_{20 v 0}\right)}{\left(1-V_{t, \rho_{t}}\right)}
$$

where the value of $V_{t}$ is given as 0.75 .

2. The estimation of the diffusion constants $1,18,33,42,54,40,79,84,100,103)$

Using Neurath's type of cell, ${ }^{7 i)}$ the diffusion constants of the proteins were estimated from the photograph of the diffusion boundary obtained by Schlielen's cylindrical lens method. ${ }^{(5,5)}$ The apparent value of the diffusion constants of proteins were calculated by the maximum ordinate method, using following equation;

$$
D \mu=\frac{\mu^{2}}{2 t} \cdot F
$$

by the maximum ordinate-area method using

$$
D_{A}=\frac{A^{2}}{4 \pi t H_{m}^{2}} \cdot F
$$

and by the moment method using

$$
D_{M}=-\frac{\sigma^{2}}{2 t} \cdot F
$$

where the area under the diffusion curve, $A$, is given by $N \cdot w, \mu$ is half the distance between both inflexion points of the curve whose height, $H \mu$, is given $H_{\mu}=-\frac{H_{m}}{\boldsymbol{e}}, H_{m}$ is the height of the peak, and $\sigma$ is the standard deviation of the curve.

The mean value of these apparent diffusion constants, $D_{m}$, was obtained. After correcting for temperature by using the equation below, the corrected value, $D_{0}{ }^{\prime}$, was obtained:

$$
D_{0}^{\prime}=D_{m}+\frac{A M_{0}}{4 H_{m} t} \cdot F
$$

The zero time correction was made by Longsworth's equation $:^{\text {i7 }}$ )

$$
D_{0}{ }^{\prime}=D_{0}(1+\Delta t / t)
$$

where $D_{0}$ is the corrected value for the diffusion constant and $\Delta t$ is a small increment added to the observed time, $t$, to correct the actual occurrence of the boundary. Thus the diffusion constant under standard conditions was obtained by the equation:

$$
D_{20 w}=D_{0}^{\prime}-\frac{\eta_{t s o l}}{\eta_{t w}} \cdot \frac{\eta_{t w}}{\eta_{20 w}} \cdot \frac{293}{273+\theta}
$$


3. The viscosity measurements

By the usual method, using Ostwald's viscosimeter, the specific viscosities of the proteins in the concentrated PAS solution were determined. The intrinsic viscosities were calculated from the following equation

$$
[\eta]=\lim _{c \rightarrow 0}\left(\eta_{s p} / c\right)
$$

4. The molecular weights ${ }^{95)}$

The molecular weights of the PAS treated proteins were calculated from the equation below;

$$
M=\frac{R T s}{(1-V \rho) D}=2.44 \cdot 10^{10} \cdot \frac{s_{20 w}}{\left(1-0.9982 V_{20}\right) D_{20 w}}
$$

where $M$ is the molecular weight, $R$ is gas constant, $V$ is specific volume of protein, $\rho$ is the density of the solvent, $s$ and $D$ represent sedimentation and diffusion constant respectively.

5. The frictional ratios ${ }^{i 4}$

Using the determined values of $s_{201}, D_{201 v}$, and $M$, the frictional ratios of the denatured proteins, $f / f_{0}$, were calculated by the following equations :

$$
\begin{gathered}
f / f_{0}=\frac{1}{6 \pi \eta}\left(\begin{array}{c}
R T \\
D N
\end{array}\right)^{2 / 3}\left[\frac{4(1-V)}{3 V s}\right]^{1 / 3}=1.00 \cdot 10^{-8}\left[\left(1-0.9982 V_{20}\right) / D_{20 w w}^{2} s_{20 w} V_{20}\right]^{1 / 3} \\
f / f_{0}=\frac{1-V \rho}{6 \pi \eta s}\left(\begin{array}{c}
4 \pi M^{2} \\
3 V N^{2}
\end{array}\right)^{1 / 3}=1.19 \cdot 10^{-15}\left[M^{2 / 3}\left(1-0.9982 V_{20}\right)\right] / s_{20 v w} V_{20}{ }^{1 / 3} \\
f / f_{0}=-\frac{R T}{6 \pi \eta N D}\left(\begin{array}{c}
4 N \\
3 V M
\end{array}\right)^{1 / 3}=\frac{2.89 \cdot 10^{-5}}{D_{20 v 0}\left(V_{20} M\right)^{1 / 3}}
\end{gathered}
$$

where $V_{20}$ is given as 0.75 .

6. The axial ratios from the frictional $\operatorname{ratios}^{43,73,77,81,85,97)}$

The values of the axial ratios of the denatured proteins, $p$, were calculated from the frictional ratios of the proteins.

$$
\begin{array}{ll}
f \mid f_{e}=-\frac{\left(1-p^{2}\right)^{1 / 2}}{p^{2 / 3} \ln \frac{1+\left(1-p^{2}\right)^{1 / 2}}{p}} & p=\frac{b}{a}<1 \text { for prolate } \\
f / f_{e}=\frac{\left(p^{2}-1\right)^{1 / 2}}{p^{2 / 3} \tan ^{-1}\left(p^{2}-1\right)^{1 / 2}} & p=\frac{b}{a}>1 \text { for oblate }
\end{array}
$$

where $\quad f / f_{e}=\left(f / f_{0}\right) /(1+w / V \rho)^{1 / 3}$

7. The axial ratios from the intrinsic viscosities $62,70,76,60)$

Calculations from the values of the axial ratios of PAS denatured proteins were made from the values of the intrinsic viscosities of the proteins by the following equations; 
$\left.\nu=\frac{\left(\frac{1}{p}\right)^{2}}{15\left[\ln \left(\frac{2}{p}\right)-\frac{3}{2}\right]}+\frac{\left(\frac{1}{p}\right)^{2}}{5\left[\ln \left(\frac{2}{p}\right)-\frac{1}{2}\right]}\right]^{-14} \frac{14}{15}-\frac{b}{a} \leqslant 1$ for prolate

$\nu=\frac{16}{15}-\frac{p}{\arctan p} \quad p=-b-a \leqslant 1$ for oblate

where $\quad \nu=\nu^{\prime}\left(1+\frac{w}{V \rho}\right)$ and $\nu^{\prime}=100[\eta] / V$

8. The measurements of the optical rotations

By Goerz Lippich's polarimeter, the specific rotations of the proteins were measured by using a sodium lamp, manufactured by Toshiba, as a light source. The accuracy of the measurements was $\pm 0.01^{\circ}$.

9. The measurements of the bound PAS by proteins ${ }^{50-601}$ )

The amounts of PAS bound by protein were measured by dialysis experiments after Klotz, using collodion bags which were prepared by collodion-ether solution. The collodion bags were filled with $10 \mathrm{cc}$ of protein solution usually near $0.5 \%$ concentration. The bag was immersed in $20 \mathrm{cc}$ of solution of the $0.05 \mathrm{M}$ phosphate buffer or $0.1 \mathrm{M}$ carbonate buffer solution of different pH's, containing different concentration of PAS, and placed in a cold room at approximately $5^{\circ} \mathrm{C}$ for a period of 5 to 7 days, an interval sufficient for the attainment of equilibrium. The bag was then removed and the external solution analysed for PAS. For each PAS concentration a control tube was also prepared, which contained only buffer solution inside the bag. The correction was made for the PAS binding by collodion membrane. About $7 \%$ of the free PAS in solution was bound by the collodion membrane.

10. The determination of PAS

The determination of PAS was carried out by the method of Tennet and Leland, ${ }^{\text {tio) }}$ using Shimazu's photoelectric colorimeter with a filter of $620 \mathrm{~m} \mu$.

11. The formation of monolayer films of PAS-denatured ovalbumin on $\mathrm{KCl}$ solution $3,10,11,16,19,20,29,38,39,41,46,47,72,99)$

Ovalbumin was dissolved in the solutions containing different concentrations of PAS, 5 to $20 \%$, and placed at room temperature, approximately $20^{\circ} \mathrm{C}$, for 30 minutes. Isopropyl alcohol was added to $30 \%$ prior to spreading on a substrate. A control spreading solution of ovalbumin was prepared by dissolving it in water and adding iso. propyl alcohol to $30 \%$.

As a substrate $0.5 \mathrm{M} \mathrm{KCl}$ aq. solution of $\mathrm{pH} 5.5$ was used.

Surface pressure was measured by Sasaki's modification of Wilhelmi's 
hanging plate method. ${ }^{85}$ The measurement were carried out at 21 to $24^{\circ} \mathrm{C}$. The surface pressure, $F$, was expressed in dyne $/ \mathrm{cm}$ and the area of the spread protein monolayer, $A$, in $M^{2} / \mathrm{mg}$.

The limiting area or co-area was obtained from the compressibility, $-(1 / A)(d A / d F)$, vs area curve of the monolayer film.

The molecular weights ${ }^{45}$ of the denatured ovalbumin obtained from the $F A$ vs $F$ lines at different concentrations of PAS were calculated by the equation below;

$$
(F A)_{F \rightarrow 0}=\frac{10^{-3}}{M}-R T
$$

\section{Results}

1. The sedimentation constants of the native and the PAS treated proteins $^{25,23)}$

The sedimentation constants of the PAS treated proteins were smaller than those of the natives, particularly in the case of hemoglobin as indicated in Table 1.

Table 1. Sedimentation constants of native and $20 \%$ PAS-treated proteins at $\mathrm{pH} 7.8$.

\begin{tabular}{c|c|c|c}
\multirow{2}{*}{ Protein } & \multicolumn{3}{|c|}{$\boldsymbol{s}_{2 \text { (nu }} \cdot 10^{13}$} \\
\cline { 2 - 4 } & Ovalbumin & Serum albumin & Hemoglobin \\
\hline Native & 3.59 & 4.45 & 4.56 \\
\hline PAS-treated & 2.70 & 3.32 & 2.01 \\
\hline
\end{tabular}

2. The diffusion constants of the native and the PAS treated proteins $^{2 \pi}$

As with the sedimentation constants, the diffusion constants of

Table 2. Diffusion constants of native and $20 \%$ PAS-treated proteins at $\mathrm{pH} 7.8$.

\begin{tabular}{l|cc|c}
\hline \multirow{2}{*}{ Protein } & \multicolumn{3}{|c}{$D_{20 w} \cdot 10^{7}$} \\
& Ovalbumin & Serum albumin & Hemoglobin \\
\hline Native & $7.76^{\mathrm{a}}$ & $6.1-6.5^{\mathrm{b}}$ & $6.30^{\mathrm{c}}$ \\
\hline PAS-denatured & 5.37 & 4.57 & 5.45 \\
\hline
\end{tabular}

a: G. Lamm, A. Polson, Biochem. J., 30, 528 (1936)

b: R. A. Kekwick, ibid., 32, 552 (1938). G. R. Cooper, H. Neurath, Chem. Revs., 30, 357 (1942). If. Neurath, G. R. Cooper, J. O. Erickson, J. Biol. Chem., $138,411(1941)$

c: A. Tiselius, D. Gross; Kolloid Z., 66, 11 (1938) 
$20 \%$ PAS treated proteins at $\mathrm{pH} 7.8$ were also smaller than those of the native ones as indicated in Table 2 .

3. The molecular weights, frictional ratios, intrinsic viscosities, and axial ratios of the native and the PAS denatured proteins ${ }^{28}$

Results obtained as summarized in Table 3.

Table 3. Molecular weights, frictional ratios, intrinsic viscosities, and axial ratios of native and PAS-denatured proteins.

\begin{tabular}{|c|c|c|c|c|c|c|c|c|c|}
\hline \multirow{3}{*}{ Proteins } & & \multirow{3}{*}{$M$} & \multirow{3}{*}{$f / f_{0}$} & \multirow{3}{*}{$100[\eta]$} & \multirow{3}{*}{$\nu^{\prime}$} & \multicolumn{4}{|c|}{$\begin{array}{l}\text { Axial ratios } w=0.3 \\
\text { calculated from }\end{array}$} \\
\hline & & & & & & \multicolumn{2}{|c|}{$f / f_{0}$} & \multicolumn{2}{|c|}{$\nu$} \\
\hline & & & & & & $\begin{array}{l}\text { pro- } \\
\text { late }\end{array}$ & oblate & $\begin{array}{l}\text { pro- } \\
\text { late }\end{array}$ & oblate \\
\hline \multirow{2}{*}{ Ovalbumin } & native ${ }^{a}$ & 45,000 & 1.16 & 4.3 & 5.7 & 3.5 & 3.9 & 3.3 & 4.0 \\
\hline & denatured & $|49,000|$ & 1.62 & 7.7 & $10 . \overline{3}$ & 8.3 & 9.8 & 6.4 & 9.3 \\
\hline \multirow{2}{*}{ Serum albumin } & native $^{\mathrm{b}}$ & 70,000 & 1.27 & 6.2 & 8.3 & 5.2 & 6.2 & 5.0 & 6.3 \\
\hline & denatured & $71, \overline{000}$ & 1.69 & 9.3 & 12.4 & 9.4 & 11.4 & 7.4 & 11.6 \\
\hline \multirow{2}{*}{ Hemoglobin } & native & 69,000 & 1.16 & 40 & 5.3 & 3.5 & 3.9 & 3.1 & 3.5 \\
\hline & denatured & $36,000^{\prime}$ & 1.77 & 10.8 & 14.4 & 10.7 & 13.3 & 8.3 & 13.7 \\
\hline
\end{tabular}

a : G. Lamm, et al., Biochem. J., 30, 528 (1936). T. Svedberg, et al., J. Am. Chem. Soc., 50, 525 (1928).

b: R. A. Kekwick, Biochem. J., 32, 552 (1938). H. Neurath, et al., J. Biol. Chem., 139, 411 (1941). T. Svedberg, et al., J. Am. Chem. Soc., 50, 3318 (1928).

c: A. Tisselius, et al., Kolloid Z., 66, 11 (1938). H. L. Fevold, Adv. Protein Chem., 6, 211 (1951)

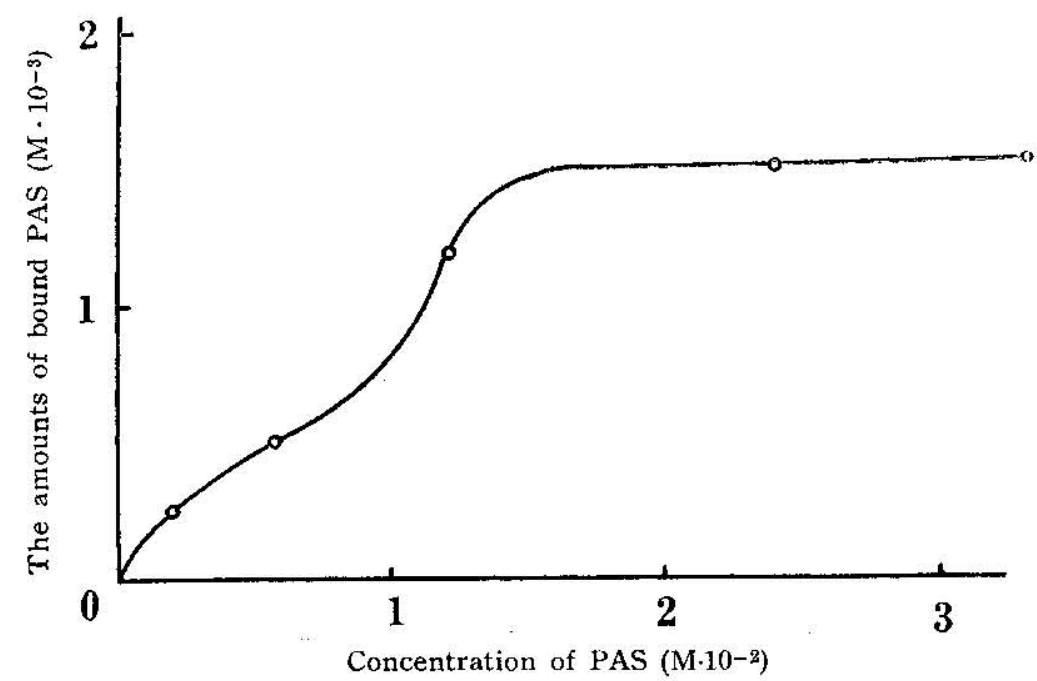

Fig. 1. The amounts of bound PAS at various concentrations of PAS, 
4. The amounts of PAS bound by ovalbumin with increasing concentrations of PAS $^{30)}$

The amounts of PAS bound by ovalbumin at $\mathrm{pH} 7.4$ in various concentrations of PAS of measured by the equilibrium dialysis method after Klotz. The concentration of protein inside the collodion bag was $1.11 \cdot 10^{-6} \mathrm{M} / 10 \mathrm{cc}$. The experiments were carried out, using $20 \mathrm{cc}$ of each of the following PAS solutions as the external solutions; 1.43 , $0.95,0.48,0.24$, and $0.10 \mathrm{M}$. The results obtained are shown in Fig. 1.

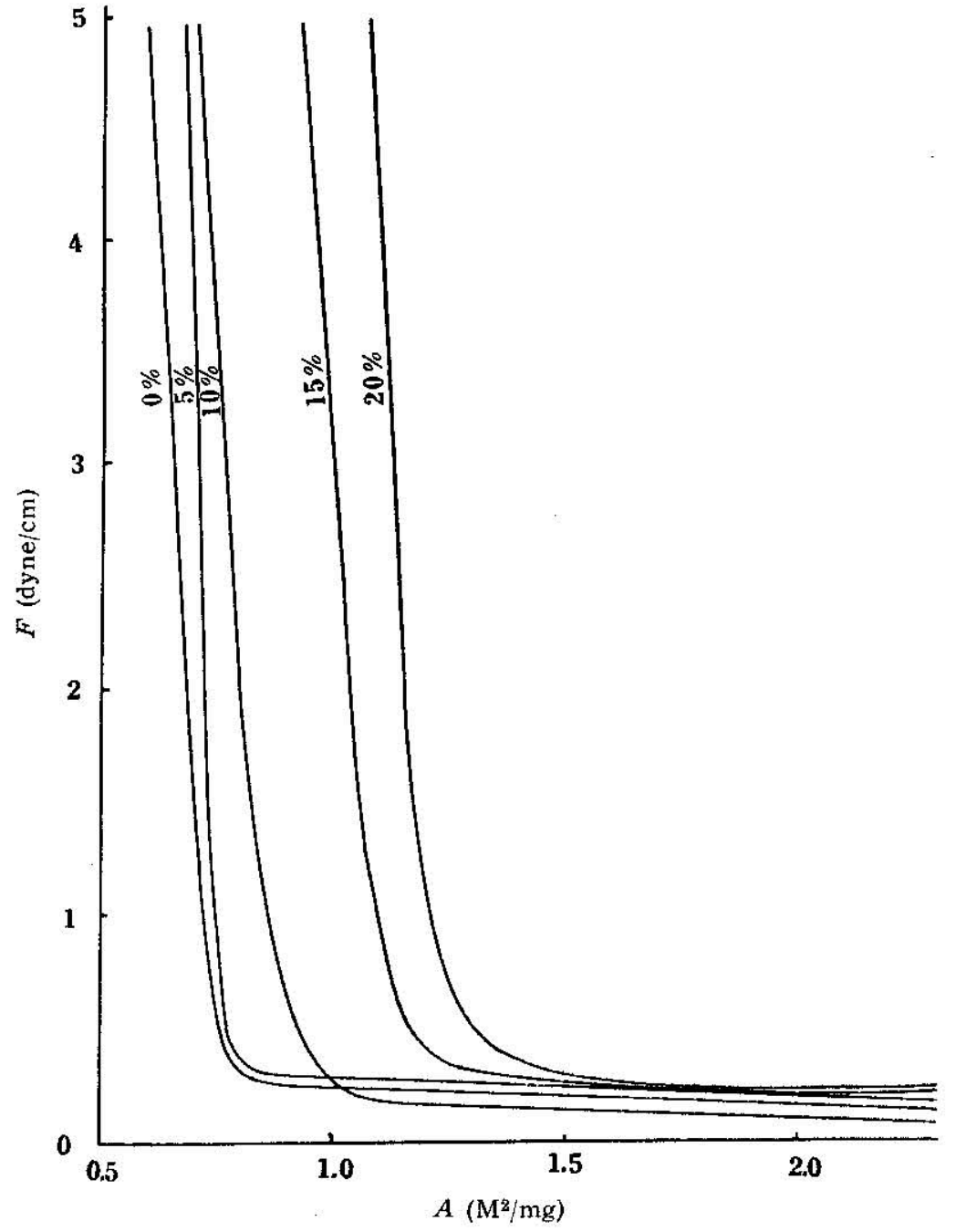

Fig. 2. The $\boldsymbol{F}-\boldsymbol{A}$ curves of ovalbumin monolayer films spread from $5,10,15$, and $20 \%$ PAS solutions respectively. 
5. The surface pressure vs area curves ( $F-A$ curves) of PAStreated ovalbumin ${ }^{31}$

The $F$ vs $A$ curves were obtained from the monolayers which were spread from the solutions of ovalbumin, containing 5 to $20 \%$ PAS, on $0.5 \mathrm{M} \mathrm{KCl}$ solution of $\mathrm{pH} 5.5$ at $21^{\circ} \mathrm{C}$ as shown in Fig. 2. The surface pressure measurements started in one hour after spreading the monolayers.

6. The limiting areas of the monolayers of PAS-denatured ovalbumin ${ }^{31}$

The limiting areas were obtained from the curves given in Fig. 2 by the method mentioned above.

Table 4 shows the relationship between the concentrations of PAS in the solutions, in which ovalbumin was treated, and the limiting areas of the monolayer films.

Table 4. The limiting areas obtained for the monolayers of denatured ovalbumin in PAS solutions of different concentration.

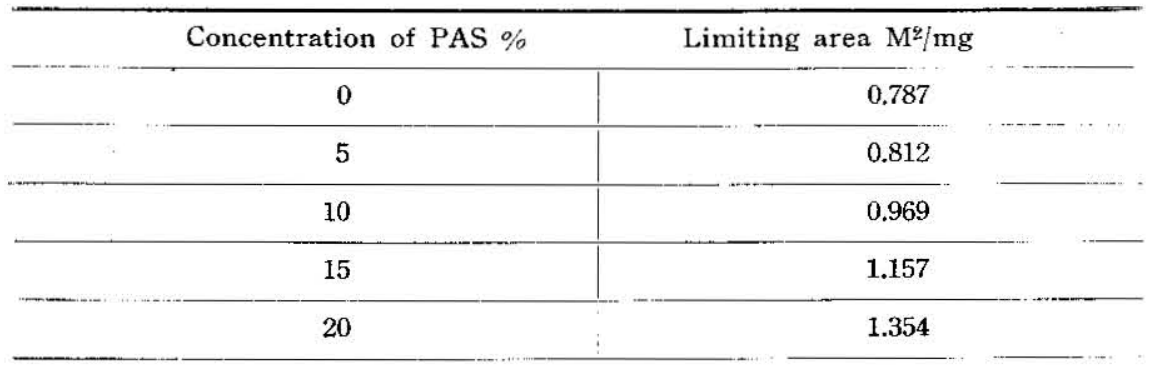

7. The $F A$ vs $F$ curves of the monolayer films of PAS-denatured ovalbumin $^{31}$ )

The values of $F A$ were calculated from the $F-A$ curves given in Fig. 2 and plotted against the values of $F$, thus obtaining the straight lines for each concentration of PAS. Moreover all the lines joined at one point on the $F A$ axis, when each was extrapolated to $F \rightarrow 0$. The value of $(F a)_{F \rightarrow 0}$ for $1 \mathrm{mg}$ protein was given as 0.053 as shown in Fig. 3.

8. The optical rotations of proteins ${ }^{29)}$

The dependence of the specific rotations of serum albumin and ovalbumin upon the concentrations of PAS in solution is shown in Fig. 4 and 5 respectively.

The optical rotations of both proteins were measured in $\mathrm{M} / 10$ carbonate buffer solution of $\mathrm{pH} 10$ containing PAS and in $\mathrm{M} / 5$ phosphate buffer solution of $\mathrm{pH} 7.7$ containing $\mathrm{PAS}$ at $8-11^{\circ} \mathrm{C}$. The crencentration of serum albumin in solutions was $0.5 \%$ and that of uvalbumin was $0.4 \%$. 


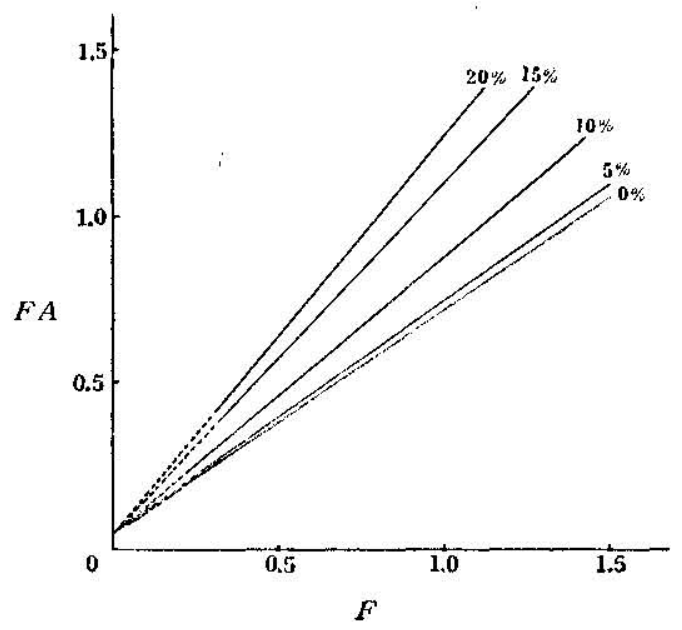

Fig. 3. The relations between $F A$ and $F$ values in different concentrations of PAS.

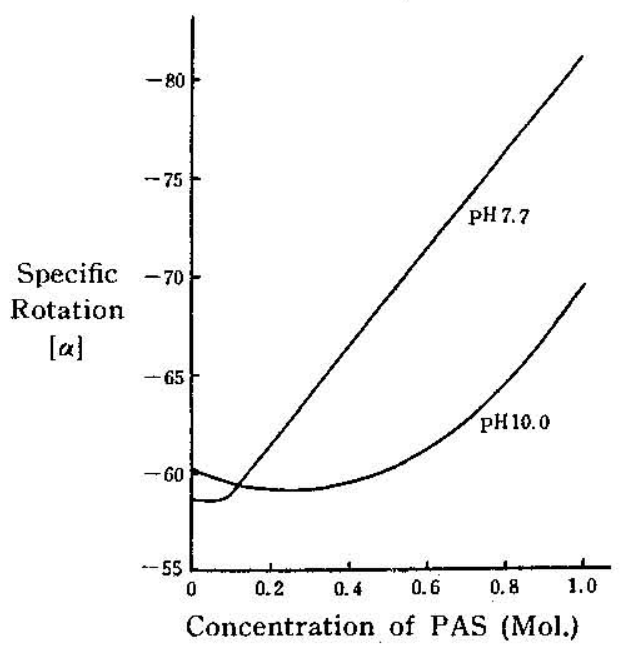

Fig. 4. The specific rotations of serum albumin at various concentrations of PAS at $\mathrm{pH} 7.7$ and 10. 


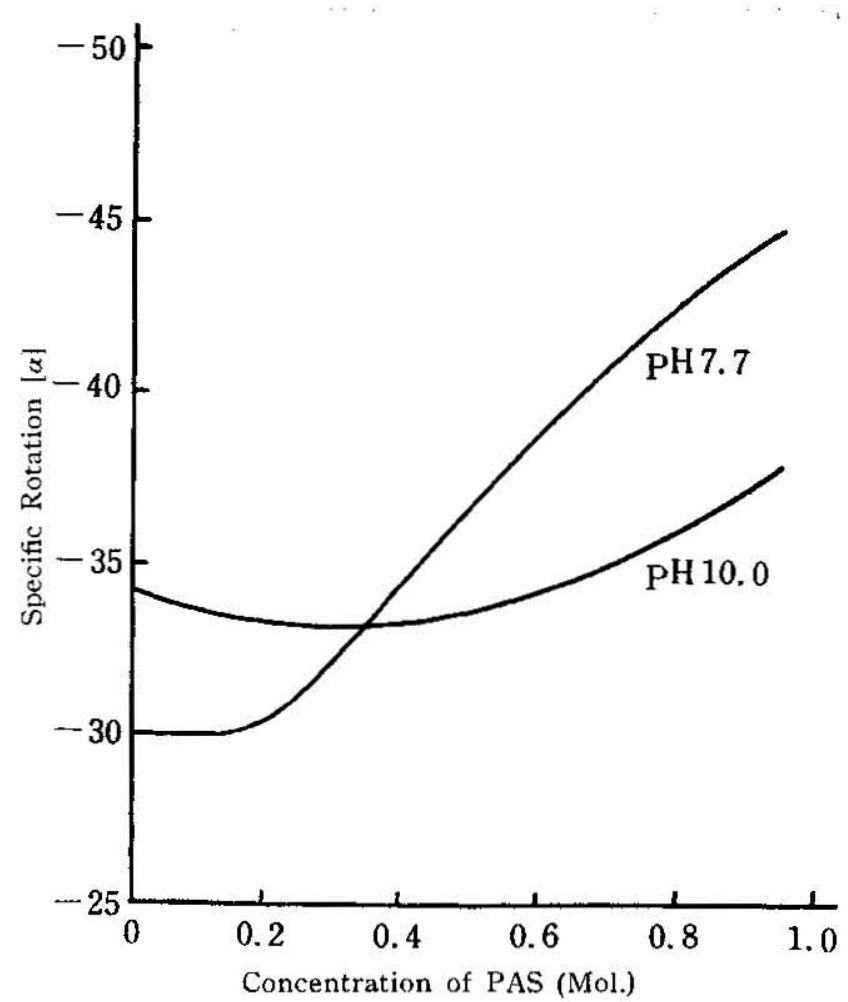

Fig. 5. The specific rotations of ovalbumin at various concentrations of PAS at $\mathrm{pH} 7.7$ and 10.

The progressive changes in the specific rotations of PAS denatured serum albumin and ovalbumin at different $\mathrm{pH}$ 's are shown in Fig. 6

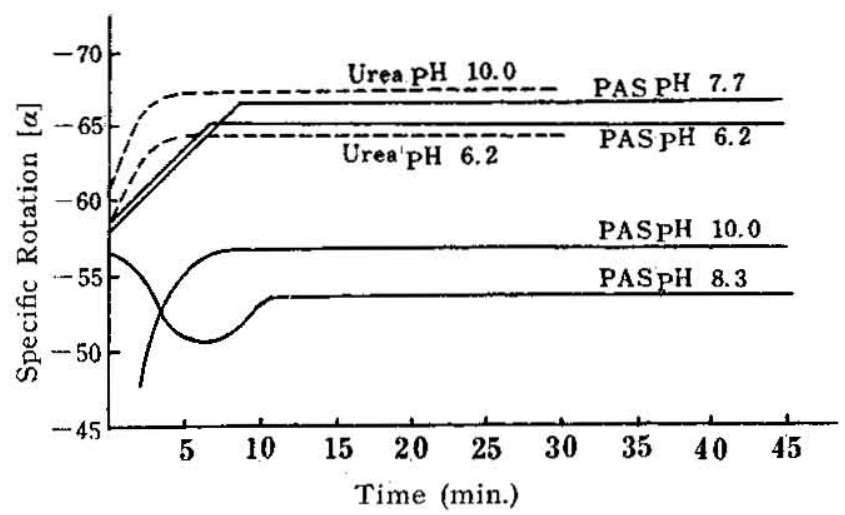

Fig. 6. The progressive changes in the optical activities of serum albumin in 10\% PAS solution of different $\mathrm{pH}$ 's at $10-11^{\circ} \mathrm{C}$. 
and 7 respectively. In these figures the values of the specific rotations are plotted with time measured in minutes. The measurements were carried out in 10\% PAS and urea solutions of $\mathrm{pH} 6.2,7.7,8.3$, and 10 . The concentration of serum albumin in PAS- and urea solution was $0.65 \%$ and $0.8 \%$ respectively and that of ovalbumin in both solutions was $0.7 \%$.

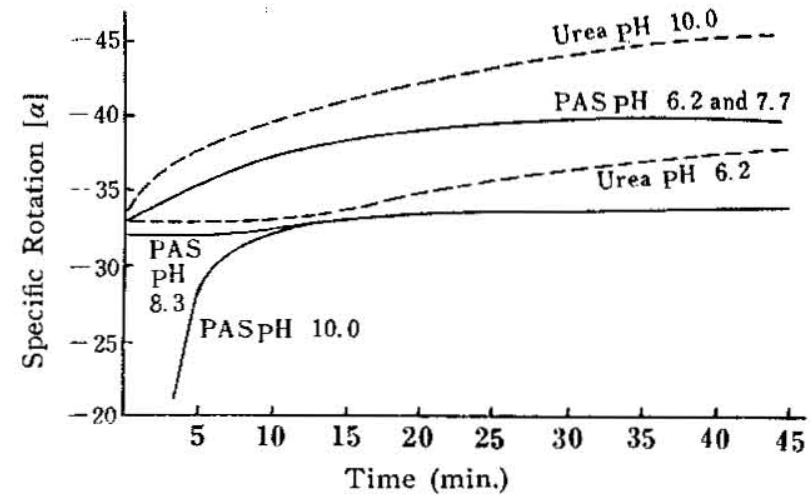

Fig. 7. The progressive changes in the optical activities of ovalbumin in $10 \%$ PAS solution of different $\mathrm{pH}$ 's at $10-11^{\circ} \mathrm{C}$.

Serumalbumin

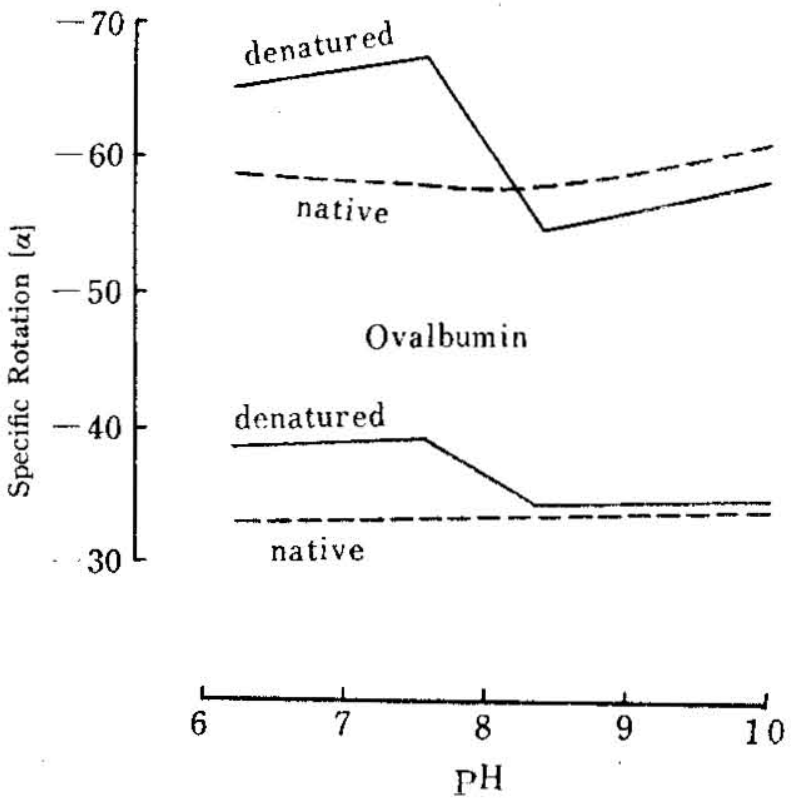

Fig. 8. The dependence of the specific rotations upon $\mathrm{pH}$, 
The dependence of the specific rotations of serum albumin and ovalbumin upon $\mathrm{pH}$ is shown in Fig. 8 . The measurements were carried out in $10 \%$ PAS solutions of different $\mathrm{pH}$ 's at $10-11^{\circ} \mathrm{C}$. The concentration of serum albumin and of ovalbumin was $0.65 \%$ and $0.7 \%$ respectively. The specific rotations of native proteins, which were dissolved in buffer solutions, were also measured in contrast with those of the PAS denatured proteins.

9. Tne dependence of the amounts of bound PAS upon $\mathrm{pH}^{30>}$

As shown in Fig. 9, the $r$ vs pH curve gave a point of the minimum value of $r$, where $r$ refers to the ratio of the moles of bound PAS to moles of total protein.

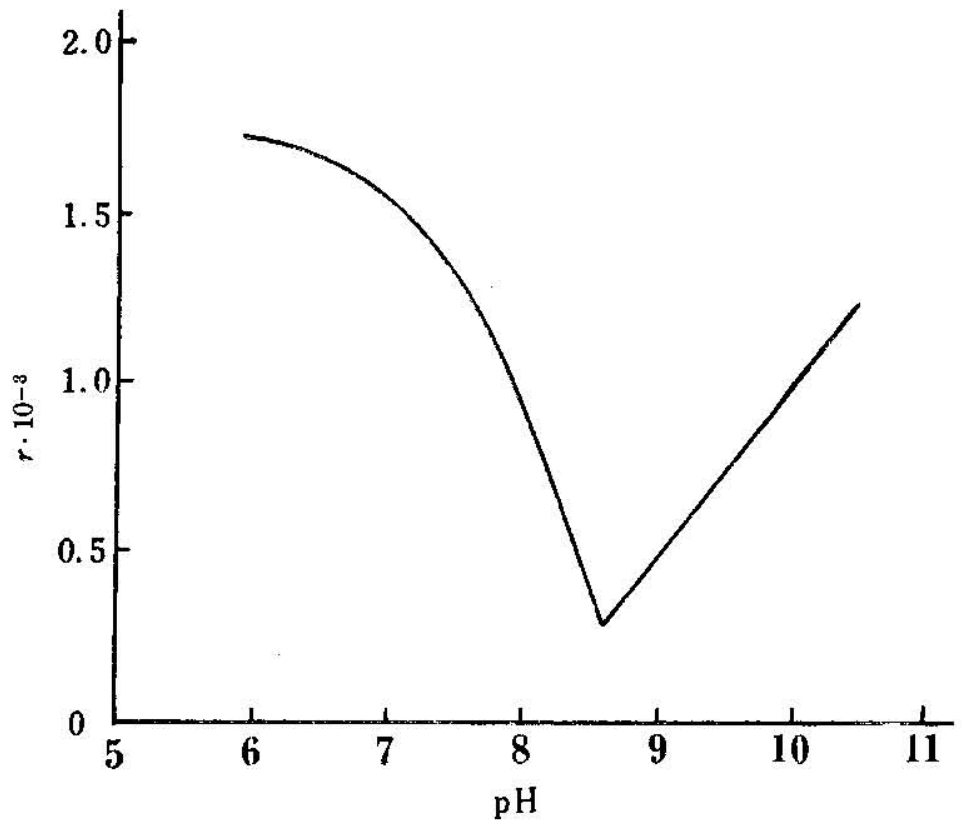

Fig. 9. The dependence of the amounts of PAS bound by ovalbumin upon $\mathrm{pH}$.

\section{DISCUSSION AND CONCLUSION}

The sedimentation constants of ovalbumin, serum albumin, and hemoglobin in concentrated PAS solutions were smaller than those of the native proteins, especially in the case of hemoglobin, for which a remarkably low value was obtained, as indicated in Table 1 . The same tendency observed in the concentrated urea solution was observed in the PAS solution. This seemed to suggest that the PAS effect did 
not depend only upon increasing the dielectric constant of the solvent, but also upon the change in the shape of the protein molecule.

It is well known that two factors influence the sedimentation constant of a protein-the molecular weight, and the shape or axial ratio of the molecule. Regard to the shape of the protein molecule, the increase in the asymmetry causes a decrease in the sedimentation constant, if the molecular weight is constant. For instance, although

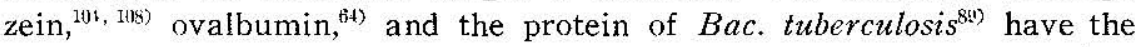
same molecular weight, approximately 40,000 , they have different values of $f / f_{p} ; 2.4,1.16$, and 1.25 and of $1 / p ; 32,3.5$, and 5.0 respectively. Thus their sedimentation constants are $1.9,3.55$, and 3.4 respectively.

The values of the diffusion constants of PAS-treated proteins were also smaller than those of the native ones, as indicated in Table 2. The decrease in the diffusion constants of the proteins suggests also a decrease in their molecular weight or an increase in their degree of asymmetry. As indicated in Table 3 , however, the molecular weights of ovalbumin and serum albumin were maintained constant in the concentrated PAS solution, unlike hemoglobin, which underwent disaggregation in the same solution. The molecular weight of the split hemoglobin molecule was one half of the native. Consequently, it was assumed that proteins in the concentrated PAS solution changed their molecular forms to those which have greater asymmetry in their molecular shape. In fact, the frictional and axial ratios, and the intrinsic viscosities of these proteins treated with PAS were greater than those of the native ones, as indicated in Table 3 . These results suggested, first, that the PAS treated protein underwent denaturation, and, second, that the molecular shape of the denatured protein was oblate. It was not prolate, since, in the case of denatured proteins, the axial ratios calculated from the frictional ratios coincided with those calculated from the intrinsic viscosities when the molecular shape was assumed to be oblate. The axial ratio of the denatured serum albumin and ovalbumin, however, were never so large, e.g., only twice as large as those of the native proteins. Therefore, it was concluded that the molecules of PAS denatured proteins were slightly enlarged transversely to their longitudinal axis. Such a change in molecular shape seemed to be due not only to the entrance of PAS molecules into proteins, but also to the formation of new hydrogen bonds with proteins. This led to the enlargement of the protein molecule. The polar PAS molecules, which were driven by their thermal movements between the peptide chains, could cleave the original hydrogen bonds between the peptide chains and bind to the liberated peptide linkages by the formation of new hydrogen bonds. In this case the negatively charged groups of PAS molecules also would combine with the liberated, positively charged groups of the protein molecules. As the results 
of these combinations, the protein molecule, which had partially dissociated, could again be refolded in a different manner from the original, and then would be in an enlarged or swollen state.

The assumption that the combination of PAS should occur inside the protein molecule was confirmed by the measuring the amounts of PAS bound by protein at different concentrations of PAS. As shown in Fig. 1, the binding of PAS by protein was assumed to take place in two steps depending upon the concentration of PAS. In concentrations of PAS lower than $0.01 \mathrm{M}$, the amounts of PAS bound by protein were relatively small. This seemed to suggest that PAS combined only with the surface of the protein molecule, which did not undergo denaturation. Secondly, in concentrations of PAS higher than $0.01 \mathrm{M}$, however, the amounts of PAS bound by protein increased rapidly, until it reached to the maximum value. This suggested that the binding of PAS occurred inside the protein molecule, whose folding had been disarranged by the denaturation. Thus the degree of denaturation seemed to be proportional to the amounts of PAS bound by protein.

On the other hand, the $F$ vs $A$ curves obtained from the spreading of monolayers of ovalbumin solutions containing 5 to $20 \%$ PAS on $0.5 \mathrm{M} \mathrm{KCl}$ solution at $\mathrm{pH} 5.5$, suggested the binding of PAS occurred inside the protein molecule, as shown in Fig. 2. These curves indicated that the area of the monolayer film produced by the PAS-denatured ovalbumin increased with an increase in the concentration of PAS. At concentrations of PAS lower than $5 \%$, the area did not increase. This same tendency was observed also in the case of limiting area of the monolayer film of the PAS-denatured ovalbumin, as shown in Table 4 .

These facts seemed to suggest that in the concentrated PAS solution, the binding of PAS by protein occurred inside the protein molecule. The amounts of PAS bound by protein depended upon the concentration of PAS and upon the degree of denaturation of the protein.

Moreover, the binding of PAS by protein was assumed to occur intramolecularly and not intermolecularly. As shown in Fig. 3, all of the $F A$ vs $F$ lines obtained at different concentrations of PAS joined at one point $(0.053)$ on the $F A$ axis, when the lines were extrapolated to $F=0$. Thus the molecular weight of PAS-denatured ovalbumin corresponded to 45,000 , the same as the native protein. This suggested that the number of the molecules of PAS-denatured ovalbumin in solution was just the same as that of the native protein. Therefore, it was concluded that association or aggregation of protein molecules did not occur during the denaturation.

Furthermore, the enlargement of the limiting area depended upon an increasing concentration of PAS. This suggested that the protein molecules combined more readily by hydrogen bonds with PAS than 
with $\mathrm{H}_{2} \mathrm{O}$ molecules. If the hydrogen bonds between the protein and PAS were weaker than between protein and $\mathrm{H}_{2} \mathrm{O}$, the PAS molecule should be removed from protein by $\mathrm{H}_{2} \mathrm{O}$, when the PAS-denatured ovalbumin is spread on water.

Consequently, it was concluded that the binding of PAS by a protein played the most important role in the denaturation of the protein with PAS.

In order to elucidate the dissociation and rearrangement of the denatured protein molecule, the optical rotation of the denatured proteins were studied.

It is well known that a protein solution changes its viscosity as

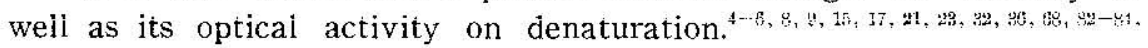
94, 201, 110) Recently, the changes in optical rotation by denaturation were studied in detail by Kauzmann ${ }^{2 i, j i-b 3,40.91)}$ and Jirgensons. ${ }^{(0,50)}$ Small changes in the inner structure of the protein molecule, which do not give changes in the viscosity of the protein solution, can be detected by measurement of optical activities. ${ }^{49}$ While the viscosity of a protein solution is concerned with the shape and degree of hydration or solvation of the protein molecule in solution, the optical activity of a protein solution is concerned with the particular structure of the protein molecule. The changes in optical rotation of the protcin solution following changes in the inner structure of the protein molecule is very sensitive.

It was suggested by Kauzmann ${ }^{51)}$ that those substances, in which there are restricted rotations of the groups about the bonds connecting them to the asymmetric centers, possess rather large optical activities in contrast to compounds in which freedom of rotation is possible. Furthermore, the total optical rotation of a given protein molecule equals the sum of partial optical rotations of the asymmetric carbons of that protein molecule. Consequently, it is assumed that many factors affect the optical rotation of proteins; i.e., whether the peptide chains are folding or unfolding, whether the protein molecules are expanding, swelling, or contracting, etc.

From the points of view mentioned above, the changes in the optical rotation of the PAS-denatured proteins are discussed.

As shown in Fig. 4 and 5, the optical activities of serum albumin and of ovalbumin in PAS solution varied with the concentration of

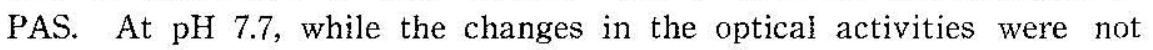
observed in both proteins until the concentration of PAS reached ca $0.1 \mathrm{M}$, in concentrations of PAS higher than $0.1 \mathrm{M}$, the optical activities of both proteins increased proportionately with the increase in concentration of PAS. At $\mathrm{pH} 10$, however, it was observed with both proteins that the optical activities began to increase gradually after the concentration of PAS reached $0.5 \mathrm{M}$. In either case, it can be said 
that the changes in the optical activities of the proteins occurred only in concentrated PAS solution, in which the amounts of PAS bound by protein were certainly large. In other words, in Iower concentrations of PAS, where PAS was assumed to combine chiefly with the surface of the protein molecule without the accompaning denaturation, the optical rotation of PAS-denatured protein was almost the same as that of the native ones. However, in high concentrations of PAS, the progressive unfolding of the peptide chains was assumed to promote the binding of PAS, by the liberated peptide linkages inside the protein molecule. Thus the large optical rotations of protein was observed here, where the large amounts of PAS were assumed to combine with protein with the accompaning denaturation.

The same interpretation as above can be given to the effect of $\mathrm{pH}$ on the PAS denaturation, i.e., a similar relationship between the magnitude of optical activity of denatured protein and the amounts of PAS bound by protein as mentioned above is observed here.

The optical activities of the proteins, which were denatured at different pH's in 10\% PAS solution for 30 minutes, are shown in Fig. 8. In a $\mathrm{pH}$ range lower than 8 , the levorotations of PAS-denatured serum albumin and ovalbumin were larger than that of the native proteins. However, in a $\mathrm{pH}$ range higher than 8 , the levorotation of denatured serum albumin was lower than that of the native protein, while that of the denatured ovalbumin was slightly higher than that of the native protein.

On the other hand, as shown in Fig. 9, the amounts of PAS molecule bound by proteins at a $\mathrm{pH}$ lower than 8 were definitely greater than those at a pH higher than 8 . At a $\mathrm{pH}$ near 8.5 the combination of PAS and protein was at a minimum. It appeared, therefore, that in the acid range the binding of PAS by protein occurred very easily and rapidly, while in a alkaline medium it occurred slowly and with difficulty.

From these data it has been concluded that the optical activities of the denatured proteins varied with $\mathrm{pH}$ in the same way as did the amounts of protein bound PAS. This seems also suggest that the situation of the peptide chains of the denatured proteins is dependent upon the $\mathrm{pH}$ of PAS solution, in which denaturation has occurred.

This assumption was confirmed by studying the progressive changes in the optical rotations of serum albumin and ovalbumin denatured by $\mathrm{P} \Lambda \mathrm{S}$ at different $\mathrm{pH}$ 's.

As shown in Fig. 6 and 7, the optical activities of serum albumin and ovalbumin in $10 \%$ PAS solution changed with time, depending upon $\mathrm{pH}$. At $\mathrm{pH}$ 's lower than 8 in the PAS solution, the levorotations of proteins increased at the same rate as in urea solution of the same $\mathrm{pH}$. The increase in levorotation of denatured serum albumin occurred 
more rapidly than that of ovalbumin. However, at a $\mathrm{pH}$ higher than 8, for instance at $\mathrm{pH} 10$, a fall in levorotations was observed in the initial stage of denaturation. Subsequently a gradual increase occurred, in the case of serum albumin, until the value of levorotation reached a level slightly smaller than that of the native protein. In the case of ovalbumin, however, the levorotation reached a slightly larger value than that of the native protein. In $10 \%$ urea solution at $\mathrm{pH}$ 's higher than 8 levorotations of both proteins increased more rapidly than in the acid $\mathrm{pH}$ range, serum albumin increasing it's optical activity more rapidly than ovalbumin.

If the protein molecules simply unfolded, the ring structure would be diminished and the extent of free rotations of groups around the asymmetric carbons would increase. Thus the protein molecule would have a partially unfolded $\alpha$-helix of peptide chains. This would cause a distinct fall in levorotation. However, a higher levorotation would be the result of the refolding of the once partially dissociated peptide chains.

Thus it was assumed that the definite fall in levorotation in the initial stage of denaturation meant that the peptide chains of the protein molecules were partially dissociated and unfolded. The gradual increase in levorotation was assumed to mean that the partially unmasked amino acid residues of the peptide chains were again bound through the PAS molecule in a relatively disordered state.

Consequently, it was concluded that during the denaturrtion of protein by PAS, the protein molecule, in any case, would be partially unfolded by PAS. At approximately the same time, PAS would combine with the liberated peptide chains, resulting in a refolding of the protein molecule. Such changes would occur in all $\mathrm{pH}$ ranges of the solution, but the rate of unfolding and of refolding would be different depending upon the $\mathrm{pH}$ of the solution. At a $\mathrm{pH}$ higher than 8 , the refolding through PAS would occur so slowly that it could be observed. How ever, at a $\mathrm{pH}$ lower than 8 , it would occur so quickly that one could not detect it.

In considering the ionization of PAS and protein at different $\mathrm{pH}$ 's, the assumptions mentioned above appear to be more definitely confirmed.

PAS is assumed to dissociate in the following four forms as shown in Fig. 10.

In this case form 1 and 2 are not considered, since these forms will exist only in strongly acid solutions which have not been studied in these experiments. The third species is the most useful for the formation of hydrogen bond, since its $-\mathrm{OH}$ and $-\mathrm{NH}_{2}$ groups have the potential forming a hydrogen bond. PAS will exist in this form at a $\mathrm{pH}$ near 7 . In an alkaline medium near 8.5 , however, PAS 
will be converted into form 4, which has only one available group, i.e., amino group, for the formation of a hydrogen bond. Here, the $\mathrm{OH}$ group of the PAS molecule will be ionized on the basis of the<smiles>NC1CCC(C(=O)O)CC1</smiles>

(1)<smiles>NC1CCC(C(=O)[O-])CC1</smiles>

(2)<smiles>NC1CCC(C(=O)[O-])CC1</smiles>

(3)<smiles>NC1CCC(C(=O)[O-])CC1</smiles>

(4)

Fig. 10.

pK'value of the $\mathrm{OH}$ group of the PAS molecule. Moreover, the dissociation of the positively charged groups of the protein molecule is also assumed to be insufficient to combine with the negatively charged groups of PAS which are present in form 4.

Therefore, it is obvious that the binding of PAS by protein is influenced by the degree of dissociation of PAS and of protein, particularly of those groups, which have the ability to form hydrogen bonds at the lower pH's, i.e., less than 8 or 9 . At pH's higher than 8 , however, the groups, which have an ability to form electrostatic bonds, also influence the binding of PAS. This, in turn, controls not only the rearrangement of peptide chains during PAS denaturation but the final state of the denatured protein as well. Thus, the optical activity of the proteins is affected by the dissociation of both the PAS molecules and the proteins as a result of the influence of intramolecular binding upon the optical rotation. For instance, the facts that in the alkaline range a definite fall in the initial stages of the denaturation and then a gradual increase occurred in levorotation of PAS-denatured protein is more easily explained by the consideration of the ionization of PAS and protein as mentioned below.

In an alkaline solution PAS exists in form 4, where the $\mathrm{NH}_{2}$ group will combine with the peptide linkages by hydrogen bonding as shown in Fig. 11.

However, the combination of $\mathrm{O}^{-}$or $\mathrm{COO}^{-}$groups of PAS with the positively charged groups of protein, whose dissociation is insufficient to cause electrostatic binding, will hardly occur. The smaller levorotation of the denatured protein in the initial stages will result from this. However, the electrostatic binding between the above mentioned groups will occur with the lapse of time. Thus the refolding by either increasing the linkage between petide chains by bound PAS molecules or reversal of the disordered folding of the peptide chains will occur. This will cause an increase in the levorotation to a certain extent. 
Since at $\mathrm{pH} 6$ to 8 , where the PAS molecule exists in form 3 , the binding of PAS by protein and the refolding of the dissociated peptide chains are assumed to occur rapidly in the initial stages of denaturation. The distinct fall in levorotation might not be observed under these experimental conditions, provided it could occur. The folding of the peptide chain of the denatured protein should be more complicated and disorderly than that of the native protein.

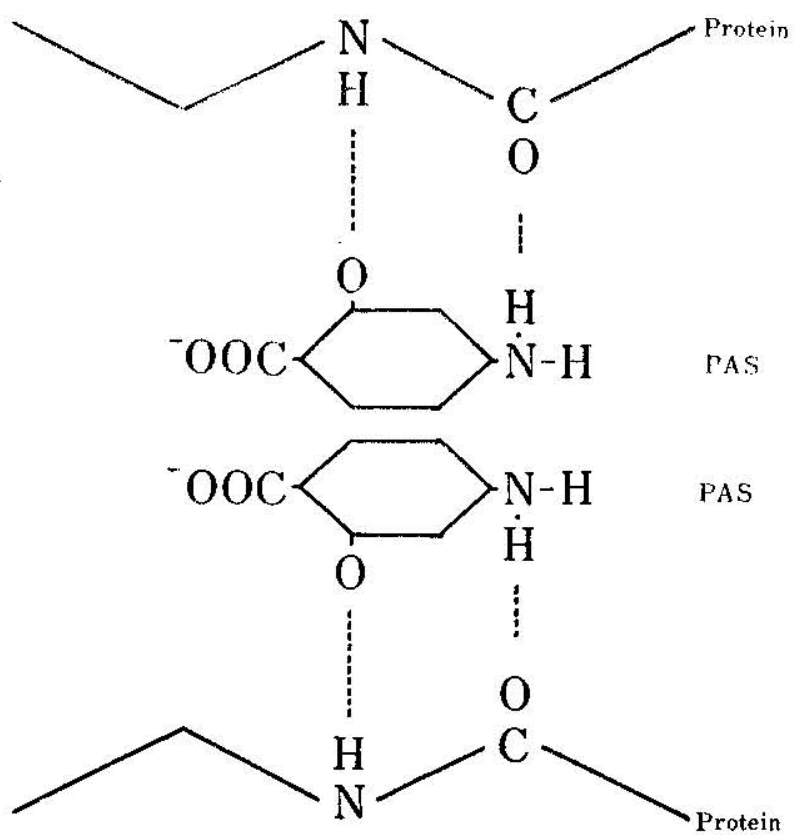

Fig. 11. The proposed scheme of the binding of PAS by protein.

The proposal of the rebinding of peptide chains through PAS seems also to be confirmed by considering the effects of sulfur-linkages upon the intramolecular changes in protein during PAS denaturation. In other words, in considering these effects of sulfur-linkages, the changes in optical activities of proteins are also clearly explained. Particularly this difference in optical activity between serum albumin and ovalbumin more clearly understood.

It is well known that the petide chains of serum albumin are folded more simply and inperfectly than that of ovalbumin. ${ }^{24,51,52,88,91)}$ The former contains many sulfur linkages, i.e., 32 half cystines in one mole compared to 2 in one more of the latter. The sulfur linkage is not considered to be cleaved during PAS denaturation.

Therefore, when the peptide chain is dissociated by denaturation, it will occur more easily with serum albumin than in ovalbumin. 
However, the final extent of dissociation is greater in ovalbumin than in serum albumin, since the former contains many sulfur linkages, by which the unfolding of the peptide chains seems to be restricted to some extent. Upon refolding the dissociated peptide chains the same sulfur linkages as above will restrict the refolding, i.e., the sulfur linkages interrupt the freedom of rotation of dissociated peptide chain leading to close, disordered contact. In acid solution, as mentioned above, since unfolding would be followed rapidly by refolding, the partially dissociated peptide chains would again be bound quickly by PAS molecules. The sulfur linkage would have little effect on the changes in the folding of the molecule. However, the rearrangement of the peptide chains by PAS with the corresponding changes in optical activity of the protein would be controlled only by the inherent folding conditions of the native proteins. Consequently, serum albumin, whose peptide chains can dissociate easily, showed more rapid and larger changes in the optical activity than ovalbumin. In alkaline solution, however, the binding of PAS by protein will occur with difficulty, as mentioned above. Although dissociation of the peptide chains will be promoted by an increase in the dielectric constant of the solution with PAS, the rebinding of the partially dissociated peptide chains by the combined PAS would occur slowly. For these reasons the distinct fall in levorotation would be determined by the effect of sulfur linkages upon the refolding of the dissociated peptide chains. Although serum albumin's ability to refold is limited to an extent by its larger number of sulfur linkages, ovalbumin will be more freely and closely refolded with the resultant larger optical activity than the native protein. In alkaline solution, the smaller levorotation of denatured serum albumin compared to the native protein and the larger levorotation of denatured ovalbumin compared to its native therefor may be explained by the above consideration.

It was concluded that binding of PAS by proteins, especially binding by hydrogen bonds play the most important role in the denaturation with PAS. The sulfur linkages are of secondary importance giving a restriction in the dissociation, on the one hand, and the subsequent refolding of the peptide chains, on the other hand. In alkaline solution the electrostatic forces seem to be important for binding of PAS by protein.

Consequently, it is concluded that PAS causes the denaturation of protein molecule in the following mechanism.

When proteins are dissociated in a concentrated PAS solution, contraction of the protein molecule will occur. Then the polar PAS molecule enters the peptide chains, destroying the hydrogen bonds. Partial unfolding of the peptide chains occurs. The PAS molecules combine with the liberated peptide linkages by the formation of new 
hydrogen bonds. The partially unfolded protein again fold up with PAS. The $\mathrm{pH}$ of the PAS solution determines the type of refolding. The refolded protein molecule is assumed to be oblate, and to be in an enlarged or swollen state.

\section{SUMMARY}

It has been discovered that in a concentrated solution of sodiump-aminosalicylate (PAS), protein underwent denaturation. To explain the mechanism of denaturation, the sedimentation constants, diffusion constants, and intrinsic viscosities of serum albumin, ovalbumin, and hemoglobin in concentrated PAS solution were measured and compared with those of the native proteins. The molecular weights, and the frictional and axial ratios of the above mentioned proteins were determinded from these measurements. From these results, it has been concluded that the denatured proteins had almost the same molecular weight as the native ones, except hemoglobin, which underwent disaggregation into half the native molecular weight. The shape of the denatured protein was assumed to be oblate. This suggested that the binding of PAS occurred inside the protein molecule and would cause the rearrangement of peptide chains and change in the shape of the protein. The binding of PAS to the protein molecule was ascertained by measuring the amounts of PAS bound by protein. The nature of the binding was studied by properties of the monolayer formed with protein denatured by PAS.

The changes in optical activities of proteins during denaturation at different pH's have given more detailed elucidation of the mechanism of denaturation.

The $\mathrm{pH}$ dependence of denaturation was explained by considering the ionization of PAS and protein. The effects of sulfur linkage of the protein molecule on the denaturation were discussed from the point of view that the rearrangement of the peptide chains of the protein molecule by denaturation was restricted by sulfur linkage.

Consequently, it was concluded that the partial unfolding of the peptide chains which was assumed to occur in the initial stage of the denaturation by the increase in the dielectric constant of the solvent by PAS, was followed by a refolding or rebinding through the bound PAS. In the rearrangement of the peptide chains, the binding of PAS to protein played the most important role, controlling the rate and the extent of denaturation. 


\section{ACKNOWLEDGEMENT}

The author is greatly indebted to Professor Y. Oshima for valuable discussions and helpful advice, and to Professor T. Isemura, Osaka University, for stimulating interest and kind support of the surface chemical studies, and also to Professor Y. Okuda, Professor I. Yamasaki and Professor K. Nishida for their encouragements and kind supports of this work. It is a pleasure to acknowledge with thanks the valuable technical assistances of Mr. and Mrs. K. Hayashi, Mr. G. Funatsu, Mr. T. Inutsuka, and Mr. K. Tokuyasu. Furthermore, the author wishes to thank Dr. Martin Sonenberg, Cornell University, for valuable suggestions and assistance during preparation of the manuscript.

\section{REFERENCES}

1) Akabori, S. and Mizushima, S., Chem. of Protein, (in Japanese) II, 382 (1954).

2) Akabori, S. and Mizushima, S., ibid., II, 386 (1954).

3) Akamatsu, H., Kagaku Jikken Gaku, Part I, Vol. 4, 66 (1940).

4) Alexander, A. C., J. Exptl. Med., 1, 304 (1896).

5) Almquist, 11. J. and Greenberg, D. M., J. Biol. Chem., 93, 167 (193i); 105, 519 (1934).

6) Aten, A., Dippel, C., Kenning, K. and Dreven, J. van, J. Colloid Sci., 3, 65 (1948).

7) Baldwin. R. L., Biochem. J., 55, 644 (1953).

8) Barker, H., J. Biol. Chem; 103, 1 (1933).

9) Bulkankin, I. N., Nagarnaya N. A. and Parina, E. V., Biokhimiya, 14, 517 (1949); C. A., 44, 3544 (1950).

10) Buil, H. B., J. Am. Chem. Soc., 67, 4, 8 (1945); J. Biol. Chem., 185, 27 (1950).

11) Bull, H. B and Neurath, H., J. Biol. Chem., 118, 163 (1937).

12) Bull, H. B. and Currie, B. T., J. Am. Chem. Soc., 68, 742, 745 (1945-1946).

13) Burk, N. F. and Greenberg, D. M., J. Biol. Chem., 87, 197 (1930).

14) Burk, N. F.. ibid., 120, 63 (1937).

15) Carpenter, D. C., J. Am. Chem. Soc., 57, 129 (1935).

16) Cheesman, D. F., Biochem. J., 50, 667 (1952).

17) Christensen, L. K., Nature, 163, 1003 (1949).

18) Coulson, C. A., Proc. Roy. Soc., A, 192, 382 (1948).

19) Cumper, C. W. N. and Alexander, A. E., Trans. Faraday Soc., 46, 234 (1950).

20) Davies, J. T., J. Colloid Sci., Sup., 9,9 (1954); Biochim. Biophys. Acta, 1', 165 (1953).

21) Desreux, V. and Fabry, C., Bull. Soc. Chim. Biol., 28, 478 (1946).

22) Dien, H. A. and Bull, H. B., J. Am. Chem. Soc., 71, 450 (1949).

23) Foster, J. F. and Young, J. T., ibid., 76, 1015 (1954).

24) Frensdorff, H. K., Watson, M. T. and Kauzmann, W., ibid., 75, 5157, 5167 (i953).

25) Funatsu, M., Funatsu, G. and Inutsuka, T., J. Agri. Chem. Soc. Japan, 30, 253 (1956).

26) Funatsu, M. and Funatsu, G., ibid,, 30, 293 (1956). 
27) Funatsu, M., ibid., 30, 298 (1956).

28) Funatsu, M., ibid., 30, 304 (1956).

29) Funatsu, M., ibid., 31, 52 (1957).

30) Funatsu, M., ibid., 31, 367 (1957).

31) Funatsu, M., ibid., 32, 265 (1958).

32) Golub, M. A. and Pickett, E. E., J. Polymer Sci., 13, 427 (1954).

33) Gosting, L. J., J. Am. Chem. Soc., 71, 1998 (1949) ; 74, 6066 (1952).

34) Gralen, N., Biochem. J., 33, 1907 (1939).

35) Gralen, N., ibid., 33, 1342 (1939).

36) Groves, M. L., Hipp, N. J. and McMeekin, T. L., J. Am. Chem. Soc., 73, 2790 (1951).

37) Gutfreund, H. and Ogston, A. G., Biochem. J., 44, 163 (1949).

38) Hamaguchi, K., J. Biochem. (in Japanese), 42, 449, 705 (1955); 43, 83 (1956).

39) Harrap, B. S., J. Colloid Sci., 9, 522 (1954).

40) Haurowitz, F., Chemistry and Biology of Proteins, 98 (1950).

41) Haurowitz, F., Boucher, P., Dicks, M. and Therriault, D., Arch. Biochem. Biophys., 59, 52 (1955).

42) Herzog, R. O., Z. Elektrochem., 13, 533 (1907); 16, 1003 (1910).

43) Herzog, R. O., Illig, R. and Kudar, H., Z. physik. Chem., A 167, 329 (1933).

44) Hewitt, L. F. and Kekwick, R. A., Biochem. J., 32, 552 (1938).

45) Ishemura, T., Symposia for the Soc. of Cellular Chem., 3, 1 (1954).

46) Ishemura, T., Hamaguchi, K. and Kawasato, H., Bull. Chem. Soc. Japan, 28, 185 (1955).

47) Ishemura, T., Protein, Nucleic Acid and Enzyme, (in Japanese), Vol. 2, 237 (1957).

48) Jacobsen, C. F. and Koosgaard, Nature, 161, 30 (1948).

49) Jirgensons, B., J. Polymer Sci., 3, 635 (1948); 4, 545 (1949); 5, 179 (1950); 6, 477 (1951); Arch. Biochem. Biophys., 39, 261 (1952); 41, 333 (1952); 48, 154 (1954); 57, 376 (1955); 59, 420 (1955); J. Am. Chem. Soc., 77, 2889 (1955).

50) Jirgensons, B. and Siratzky, S., Arch. Biochem. Biophys., 52, 400 (1954).

51) Kauzmann, W. and Eyring, H., J. Chem. Phys., 9, 41 (1941).

52) Kauzmann, W. and Simpson, R. B., J. Am. Chem. Soc., 75, 5154 (1953).

53) Kauzmann, W., The Mechanism of Enzyme Action, 70 (1954).

54) Kegeles, G. and Gosting, L. J., J. Am. Chem. Soc., 69, 2516 (1947).

55) Kekwick, R. A. and Cannan, R. K., Biochem. J., 30, 232 (1936).

56) Klotz, 1. M., Walker, F. A. and Pivan, B. B., J. Am. Chem. Soc., 68, 1486 (1946) ; 69, 1609 (1947).

57) Klotz, I. M. and Curme, H. G., ibid., 70, 939 (1948).

58) Klotz, I. M., Triwush, H. and Walker, F. M., ibid., 70, 2935 (1948).

59) Klotz, I. M., Arch. Biochem., 9, 109 (1948).

60) Klotz, I. M., Neurath, H. and Baily, K. edited: The Proteins, II, 727 (1953).

61) Kondo, K., The Phys. Chem. of Protein (in Japanese), 8 (1927).

62) Kraemer, E. O. and Lansing, W. 1)., J. Phys. Chem., 39, 153 (1935).

63) Krejcin, L. and Svedberg, Th., J. Am. Chem. Soc., 57, 946 (1935).

64) Lamm., O. and Polson, A., Biochem. J., 30, 528 (1936).

65) Longsworth, L. G., Ind. Eng. Chem., Anal. Ed., 18, 219 (1946).

66) Longsworth, L. G., J. Am. Chem. Soc., 69, 2510 (1947).

67) McBain, J. W., Colloid Science, 218 (1950).

68) McLaren, A. D., Adv. Enzymol., 9, 75 (1949).

69) McMeekin, 'T. L., J. Am. Chem. Soc., 61, 2884 (1938); 62, 3393 (1940). 
70) Mehl, J. W., Oncley, J. L. and Simha, R., Science, 92, 132 (1940).

71) Mizushima, S. and Akabori, S., Chem. of Protein (in Japanese), II, 355, 371 (1954).

72) Mizushima, S. and Akabori, S., ibid., II, 597 (1954).

73) Mizushima, S. and Akabori, S., ibid., II, 359, 360 (1954).

74) Mizushima, S. and Akabori, S., ibid., II, 360, 36 I (1954).

75) Neurath, H., Science, 93, 431 (1941).

76) Neurath, H., Greenstein, J. P., Putnam, F. W. and Erickson, J. O., Chem. Revs., 34, 158 (1944).

77) Neurath, H. and Baily, K., The proteins, I, B, 643 (1953).

78) Neurath, H. and Baily, K., ibid., I, B., 689, 690 (1953).

79) Northrop, J. H. and Anson, M. L., J. Gen. Physiol., 12, 543 (1929).

80) Oeholm, L. W., Z. Physik. Chem., 50, 309 (1905); 70, 378 (1910).

81) Onkley, J. L., Ann. N. Y. Acad. Sci., 41, 121 (1941).

82) Pauli, W. and Weiss, R., Biochem. Z., 233, 381 (1931).

83) Pauli, W. and Hofman, L., Kolloid Beihefte, 42, 34 (1935).

84) Pauli, W. and Kölbl, W., ibid., 41, 418 (1935).

85) Perrin, F., J. Phys. radium, (7), 7, 1 (1936).

86) Roche, J., Adair, G. S. and Adair, M. F., Biochem. J., 26, 1811 (1932).

87) Sasaki, T., J. Chem. Soc. Japan, 62, 796 (1941).

88) Schellman, J., Simpson, R. B. and Kauzmann, W., J. Am. Chem. Soc., 75, 5152 (1953).

89) Seibert, F. B., Pedersen, K. O. and Tiselius, A., J. Exptl. Med., 68, 413 (1938).

90) Simha, R., J. Phys. Chem., 44, 25 (1940).

91) Simpson, R. B. and Kauzmann, W., J. Am. Chem. Soc.. 75, 5139 (1953).

92) Sörenson, S. P. L. and Höyrup, M., Z. physiol. Chem., 103, 15 (1918).

93) Steinhardt, J., J. Biol. Chem., 123, 543 (1938).

94) Strachitsky, K. I., Doklady Akad. Nauk, U. S. S. R., 58, 1423 (1947); C. A., 46, 4590 (1952).

95) Svedberg, Th., Z. physik. Chem., 127, 51 (1927).

96) Svedberg, Th., and Brohult, S., Nature, 142, 830 (1938); 143, 938 (1939).

97) Svedberg, Th. and Pedersen, K. O., The Ultracentrifuge, (1940).

98) Svensson, H., Kolloid Z., 90, 141 (1940); 87, 181 (1939).

99) Tachibana, T., Chem. of Protein (in Japanese) (S. Mizushima and S. Akaobri ed.) II, 597 (1954).

100) Tennet, D. M. and Leland, M. L., J. Biol. Chem., 177, 873 (1949).

101) Timasheff, S. N. and Nord, F. F. Aach. Biochem.Biophys., 31, 309 (1951).

102) Wall, F. T., Grieger, P. F. and Childer, C. W., J. Am. Chem. Soc., 74, 3562 (1952).

103) Wall, F. T. and Childer, C. W., ibid., 75, 3550 (1953).

104) Watson, C. C., Arrhenius, S. and Williams, J. W., Nature, 137, 322 (1956).

105) Weber, H. H., Ergeb. Physiol., 36, 109 (1934); Biochem. Z., 266. 137 (1933).

106) Weber, H. H. and Stöver, R., ibid., 259, 269 (1933).

107) Wernicke, R., Nature, 136, 30 (1935).

108) Williams, J. W. and Watson, C. C., Cold Spring Harbor Symposia Quant. Biol., 6, 208 (1938).

109) Yoshinari, M., J. Kyushu Hematological Soc., 2, 47 (1952); 4, 107 (1954).

110) Young, E. G., Proc. Koy. Soc., (London) B, 93, 253 (1922).

Laboratory of Biochemistry

Faculty of Agriculture

Kyushu University 